\title{
The Child in Question
}




\section{Other books by Diana Gittins}

\section{Non-fiction}

Fair Sex: Family Size and Structure 1900-1939

The Family in Question: Changing Households and Familiar Ideologies (second edition)

\section{Poetry}

Dance of the Sheet 


\title{
The Child in Question
}

\author{
Diana Gittins
}

Consultant Editor: Jo Campling

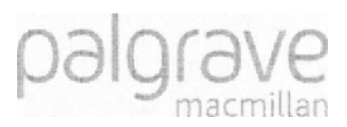




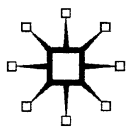

(C) Diana Gittins 1998

Softcover reprint of the hardcover 1st edition 1998

All rights reserved. No reproduction, copy or transmission of this publication may be made without written permission.

No paragraph of this publication may be reproduced, copied or transmitted save with written permission or in accordance with the provisions of the Copyright, Designs and Patents Act 1988, or under the terms of any licence permitting limited copying issued by the Copyright Licensing Agency, 90 Tottenham Court Road, London W1T 4LP.

Any person who does any unauthorised act in relation to this publication may be liable to criminal prosecution and civil claims for damages.

The author has asserted her right to be identified as the author of this work in accordance with the Copyright, Designs and Patents Act 1988.

Published by

PALGRAVE MACMILLAN

Houndmills, Basingstoke, Hampshire RG21 6XS and

175 Fifth Avenue, New York, N. Y. 10010

Companies and representatives throughout the world

PALGRAVE MACMILLAN is the global academic imprint of the Palgrave Macmillan division of St. Martin's Press, LLC and of Palgrave Macmillan Ltd. Macmillan ${ }^{\circledR}$ is a registered trademark in the United States, United Kingdom and other countries. Palgrave is a registered trademark in the European Union and other countries.

ISBN 978-0-333-51109-1

ISBN 978-1-349-26092-8 (eBook)

DOI 10.1007/978-1-349-26092-8

This book is printed on paper suitable for recycling and made from fully managed and sustained forest sources.

A catalogue record for this book is available from the British Library. 
For Emily, Giovanni and their children with love 


\section{CONTENTS}

List of Illustrations

ix

Foreword

Preface

Acknowledgements

xviii

Introduction 1

Theory? What Theory? $\quad 12$

1 Is Childhood Socially Constructed?

History and Childhood 26

Different Children, Different Lives 32

Children and Nature $\quad 38$

If it's all Constructed, is it all Just a Story?

2 Who Owns Children? 46

Slavery 49

Illegitimacy $\quad 53$

Work $\quad 57$

Education $\quad 69$

In Whose Best Interests? $\quad 74$

3 Is there a Child Within? 80

The Child and Interiority $\quad 81$

The Unconscious $\quad 84$

Projection $\quad 90$

Poisonous Pedagogy? 94

Memories, Violence, Mothers 99 
viii The Child in Question

4 What do Children Represent? 109

Paintings

Family Photographs

Myths, Stories and Fairy Tales

A Story of the Nation?

5 Are Children Innocent? 145

Original Sin, Tabula Rasa or Naturally Good? $\quad 146$

Representations of Innocence in Literature 153

6 Children's Sexuality: Why do Adults Panic? 173

What is Sexuality? 175

The Cleveland Crisis 180

Body/Mind 185

The Great Masturbation Debate 191

Desire for Children 197

$\begin{array}{ll}\text { Conclusion } & 202\end{array}$

Notes $\quad 208$

Bibliography 213

Index $\quad 227$ 


\section{List OF ILLUSTRATIONS}

Figure 1 Hogarth, The Graham Children 114

Figure 2 Cambodian boys cool off in Tonle Sap river 115

Figure 3 Hans Memlinc, The Virgin and Child 120

Figure 4 Frans Hals, Catharina Hooft with her Nurse 122

Figure 5 Lebanese girl and apple 124

Figure 6 Goya, The Family of the Duke of Osuna 126

Figure 7 Gainsborough, The Painter's Daughters Chasing a Butterfly

Figure 8 Millais, Sweetest Eyes were Ever Seen 130

Figure 9 Family photograph: Repulsive II (i) 134

Figure 10 Family photograph: Repulsive II (ii) 134

Figure 11 Family photograph: mother and daughters 134 


\section{FOREWORD}

In might well be thought, in the final decade of the twentieth century, given the frequency of international horror stories involving children, that the status of childhood has improved little, if at all, since the world of Dickens, Lamb or Alcott. Neither the plethora of legislation, the good intentions of the welfare professionals nor the vigilance of investigative jornalists have proved to be the guarantee of empowerment or fulfilment for children as a group.

In writing this book Diana Gittins has simultaneously attempted to wrestle back the theory and practice of childhood from the grasp of the 'experts' whoever they be - sociologists psychologists, social workers, politicians - and to give them back in return a genuinely child-centred account of what it means, or what it might mean, to be a child. In doing so she illuminates the path for adults, including students and practitioners, to bodies of knowledge which might simultaneously enhance our understanding of children, childhood, and our own experiences. She reunites the personal and political in a way that ought to provide new incentives for grappling with the systems without imposing yet another straight-jacket on a group to which we've all belonged. 


\section{PREFACE}

It was the trees that set me off: the wild orange, red and gold of them. I could smell dank piles of raked leaves, wood smoke, pine needles, the vapour rising from damp dirt roads. I could hear the crack of a baseball bat spinning a ball into crisp blue sky, the sound of laughter, the song of the chickadees. I could taste icecold apple cider from a flagon bought at a roadside stand. I could feel the slime of stringy pumpkin flesh entwined with hundreds of viscous seeds that my sister and I scooped out ready for mother to carve the macabre face on a jack-o-lantern.

I was sitting in a cinema in Oxford Street, London watching $A$ League of their Own. Neither the narrative nor the acting moved me, but the landscape and the colours of upstate New York in the 1940s brought back, like Proust's notorious madeleine, a rush of memories. I felt euphoric. I wanted to go back there, to return to the place of my childhood. Suddenly I felt I had to go back, back to the land I'd left 35 years ago. I had to go back to that ecstasy of childhood bliss.

What was peculiar, however, was that I had spent much of the past few years in therapy and in groups exploring and abreacting the horrors and pains of childhood. I had scooped out much of the twisted and viscous mass of negative emotions that had come from the jack-o-lantern of disturbed parents, sexual abuse and betrayal. The face of it was hideous; etchings of rape and leering psychosis were in the orange secrecy that now shone eerily in my front window, scaring away all but the most intrepid of trick-ortreaters.

So where had all these ecstatic memories come from so suddenly, so unexpectedly? Of course, I always knew there had been 
good times: going by sled through the snow with my father to cut down a Christmas tree; long, hot summers on the Rhode Island coast. After we left upstate New York there were years spent at a progressive school in the hills of Vermont, where we grew up among interesting intellectuals and artists, many seeking a haven from the horrors of the McCarthy witch hunts. I remembered my mother leading the Harvest Festival on a motorbike, then cartwheeling across fields in the September sun. I remembered Fernando Gerassi, friend of Sartre and de Beauvoir, standing on his bald head at my request in the school entrance. I remembered meeting Eleanor Roosevelt. I remembered my friend's parents who, deeply committed to the theories of Wilhelm Reich, used to sit naked in a kind of shower cubicle - the 'orgone box' - in the middle of their kitchen, chaotic with cats, children, old-fashioned milk cans and freshly picked apples. I remembered the freedom of roaming dirt roads, totally without adult supervision, exploring the pleasures of woods and streams and what seemed to be an endless, timeless scope for imaginative play.

All this contrasted so markedly with memories of being made to pose for pornographic photographs by my father. It contrasted with memories of my mother taking me to bed with her lover. It contrasted with my sister's intense, pathological hatred of me. It seemed so far removed from the all-pervasive terror I remembered - terror that kept me from school; terror that, after being raped when I was seven, left me with epileptic fits. And so I began to wonder, who was this child? Were there, in fact, two children, two childhoods? What does it mean to have been two children, two girls? It seems that the public face of my childhood, the sense of self built up by family narratives and photographic albums (there were no pornographic photos stuck in there) contradicted the painful memories hidden, so long unacknowledged and unexpressed in my unconscious. And yet, long before I went into therapy, I had an uneasy sense that there were other things more painful, that something had gone terribly wrong.

These questions led to more general ones. Is this, I wondered, how other children experienced childhood(s)? Could my own childhood have been in any way typical, or was I indeed some kind of freak outside of childhood altogether? What is this strange being we call 'the child' that seems to be everywhere inside my mind, my memory, my photograph album - but co- 
exists with, and often contradicts, images and narratives in films, advertisements, television, books and articles? Who is this that seems both familiar and alien, puzzlingly both adored and feared? How does my own sense of having had a double childhood correspond to broader cultural notions of childhood? How typical had been my experience of cruelty and abuse juxtaposed with the delights of a privileged middle-class upbringing in beautiful environments? How do all these questions relate to the material situation of other children worldwide: girls, boys, African, Asian, Muslim, Jewish, poor, ill, rich, hungry, homeless? When is a child not a child, and if a child is not a child, who makes such pronouncements?

As I reflected on these questions, so the apparently simple concept of 'the child' became increasingly complex and contradictory. There seemed to be so many children, so many childhoods. The child', I concluded, exists at a number of levels: the personal level (both conscious and unconscious, memoried and forgotten); the material level, both in relation to embodiment, and in relation to access to various material resources; and at a cultural and representational level in art, photography, narratives of all sorts, and advertisements. As a result of these insights, however, I came to realise that, for me, 'the child' could only be studied in a diverse, eclectic and interdisciplinary way. This may be considered by some to be an unconventional approach, and warrants an account of how I came to arrive at it.

Soon after I finished writing The Family in Question - in that ominous year, 1984 - I resigned an academic post as Lecturer in Sociology. Interested in social history, historical demography and the history of the family, my academic work until then had been greatly informed and influenced by Marxism and feminism. My primary focus was on material inequalities and injustices between social classes, and between women and men. Theories of social class, however, seemed woefully inadequate in explaining gender inequalities. The concept of patriarchy, though problematic, attracted me at this time, because it offered some insights into these. I was also influenced by Foucault and poststructuralist theories that brought attention to the importance of power, power relations and resistance. These I saw, and continue to see, as crucial determinants of inequalities affecting women, men and children. My second book, The Family in Question, was a 
result of these influences, in conjunction with many years of having to teach 'the family' using texts that I regarded as hopelessly outdated, based as they were on 1950s functionalist theory.

After writing it, however, something shifted for me. A series of tragedies in my own family led me into questioning the importance of more subjective and emotional aspects of families, living conditions and, indeed, 'the self'. I went into therapy and immediately began to confront a tidal wave of emotions and memories long hidden and denied. Neither sociology nor social history offered me any insights or explanations to these. Nor did Marxism or Foucauldianism. Emotion did not seem to be on the agenda of social science.

The world of emotions, transference and painful recall of my personal past jarred my 'sociological self' to the core. It has never fully recovered, though it has been part of the development of a more eclectic self. As I began to understand some of the reasons why I was who (I thought) I had become, old patterns started to fall apart. I read and re-read Freud, delved into Jung, Klein and Irigaray. I became fascinated by the workings and manifestations of the unconscious, both in theoretical writings and in my own experiences in therapy and dreaming. I also became acutely aware of how important 'the child' that (I thought) I had once been remained to who (I thought) I might be(come).

Six months after beginning therapy I gave up smoking (80 cigarettes a day!), gave up drinking two litres of black coffee a day, and stopped taking barbiturates, which I had been prescribed for over 27 years. I began to dream for the first time since I was nine years old (barbiturates suppress dreaming). During this time I also began to write - and read and re-read - poetry. I grew to realise how important images and imagery are, not just in poetry and dreams but in culture generally. I became fascinated with metaphor, symbolism and myth. All these 'irrational' phenomena seemed to offer insights and understanding in a way social science had never done. They helped me to understand my feelings, other people's feelings, my childhood memories, and offered insights into the irrational aspects of my thought processes and behaviour. The aesthetic aspect of them seemed vital; not just images, but the sounds and rhythm of words were part of a growing pleasure in language itself.

I began to value, appreciate and explore my own imagination, 
my creativity, and indeed the whole subjective 'irrational' aspect of my self which I had so long suppressed and denied, but which had also been denied, it seemed to me, by sociological theory. The ways in which things stood for other things - ways in which things were represented by imagery, metaphor and metonymy in language, dreams, and poetry - seemed to me to be an incredibly important aspect of self, culture, living. A healthier body, a body that felt as if it was melting after being frozen in ice for most of my life, made me increasingly aware of the importance of my own embodiment, a supreme material reality that Marxism had never, as it were, touched.

For several years I could not see how these discoveries could in any way be reconciled with my earlier beliefs and experiences. My own material poverty during this time seemed irrelevant in contrast to the revelations and insights I felt I was achieving. Although the childhood memories tapped in therapy were often excruciatingly painful, the release of them, the relief of bringing them into the light contributed to what I can only describe as a feeling of rebirth, or perhaps renovation would be more apt. It eventually led to the publication of a collection of my poetry, Dance of the Sheet.

Poverty, however, began to take its toll; proof, I suppose, of the validity of many of the theories I had recently been rejecting. I started working for the Open University as a consultant to the Women's Studies course team. Here I realised social science had not stood still during the time I had been spiralling into my psyche. Feminism and social science had joined hands with postmodernism, it seemed, to tackle some of the issues I had been confronting at a purely personal level. Postmodernist theory, for instance, raised important issues about subjectivity and identity and the construction of these through discourse and culture. For someone who felt deeply divided as a result of therapy and confrontation with a traumatic, hidden past, the discovery that postmodernist theory propounded the idea that we are all fragmented was deeply satisfying!

History, poetry/representation, psychoanalysis, postmodernism, feminism, Marxism - these have been the bodies of ideas that have most influenced me and which I draw on in this book around the theme of 'the child'. There are aspects of all of them that relate directly to the theme, yet I cannot, and will not, single 
out one perspective as the appropriate way in which to approach the subject. Perhaps such an eclectic approach weakens the possibility of formulating a neat, rational and logical argument or theory. I do believe, nevertheless, that it is imperative to understand 'the child' at different levels, because all these levels in the end are interrelated and affect one another.

Our own memoried and unconscious child and childhood affect what we think the child, children, childhood and childrearing are and should be. Our beliefs and memories are partly determined by wider cultural discourses, but they also feed into and contribute to these. Discourses, meanings and beliefs do not just float aimlessly in air. They are used to justify, rationalise and implement behaviours, policies and legislation. These inform and construct, and are in turn informed and constructed by, power relations of all sorts. These then affect children - and adults - in material ways and discursive ways which we experience as embodied beings.

If we try to understand 'the child' without acknowledging the centrality of our own experiences we stand in danger of making one-sided judgements and taking one-dimensional actions that deny a vital aspect of the meanings of 'the child' and 'childhood' in humanity and culture. I argue here that this is exactly what tends to happen; by denying the darker more shadowy and unconscious side of our selves, we end up denying its existence in everyone, including children. If we define children as angels, we also create a need for devils, because those aspects of children and of ourselves that we cannot accept as good must be directed, projected somewhere else. By doing this we project unwanted aspects of our selves on to others who are then stereotyped and scapegoated as Other.

Much of this book, therefore, focuses on the darker, more negative aspects concerning 'the child' and what it means to adults. I do not mean to neglect or ignore the more positive and happy aspects of 'the child' and 'childhood', which undoubtedly mean an enormous amount to all of us. Rather, I am interested in the contradictions between the positive ideas and hopes for 'the child', and the irrational, apparently dark and negative ways in which adults frequently act towards children, and, indeed, how children themselves can behave in ways adults regard as unacceptable and transgressive. Crucial to my argument overall is that 
only by trying to take on board the more negative and unacceptable aspects both of ourselves and of children are we likely to be able to move towards change.

Diana Gittins 


\section{ACKNOWLEDGEMENTS}

This book has been a long time in the making. I would like to thank, therefore, both Frances Arnold and Catherine Gray, my editors at Macmillan, for their patience. Jo Campling has given me much help and advice throughout this protracted process and I would also like to thank her. I am very grateful to the staff of the Totnes Library, who diligently dealt with an endless succession of inter-library loan requests during a period when I had no access to academic library facilities. I would also like to thank my students on the freshman seminar 'What is a Child?' at Colgate University, who contributed to many lively discussions and were very kind to me during a difficult time. Most of all, however, it has been my dear and good friends who have given me no end of support and helped me to believe that eventually I would be able to finish this book. To them I owe the greatest debt and would like to thank them all, especially Joan Busfield, Isabel Cabot, John Daniel, Yasmin David, Leonore Davidoff, Felicity Edholm, Frankie Finn and Sarah Hopkins.

The author and publishers would like to thank the following illustration sources:

The Guardian pp. 115 (photographer Richard Vogl), 124; Museo del Prado, Madrid p. 126; The National Gallery, London pp. 114, 120, 129; The National Gallery of Scotland, Edinburgh p. 130; Staatliche Museen Preussischer Kulturbesitz Gemaldegalerie p. 122.

The photographs on p. 134 were supplied by the author.

Every effort has been made to trace all copyright holders but if any have been inadvertently overlooked the publishers will be pleased to make the necessary arrangements at the first opportunity. 